\title{
PENDIDIKAN PEREMPUAN: Kajian Sejarah yang Terabaikan
}

\author{
Oleh: Samsul Nizar*
}

\begin{abstract}
In historical study, the woman character constitutes ignoring study. Whereas, the existence of woman always is discussed in some events and some fields, without exception of educational study, even in the classical period until nowadays. But, the woman is merely considered as explanation object. It means it often appears in thought discourse is the women as object thought not as subject thought itself. Therefore, it is worth opening books or scriptures, so that, their indexes are filled with men's names, moreover, the women's names are only mentioned if the study talks about woman history. Even though, it does not mean that, there is not woman character appearing and mastering knowledge in some fields. The fields that get attention from woman character namely; Islamic law, poem, and mysticism.
\end{abstract}

KEYWORDS: Pendidikan, tokoh perempuan, ilmu, figh nisä'

DISADARI bahwa tidak banyak, untuk tidak mengatakan tidak ada, tokoh perempuan yang muncul dalam lembar sejarah dunia Islam, khususnya pasca masa Rasulullah dan para sahabatnya. Posisi perempuan yang pada masa periode awal Islam ikut terlibat aktif dalam kehidupan masyarakat dan berperan dalam berbagai bidang - tidak hanya dalam wilayah domestik, tetapi juga dalam wilayah publik - kian tenggelam di tengah-tengah puncak kejayaan Islam, dan semakin terpuruk dalam masa-masa dominasi Eropa pada belahan dunia muslim lainnya.

Tidak dipungkiri bahwa perempuan selalu didiskusikan dalam berbagai kesempatan dan berbagai bidang, tidak terkecuali dalam bidang pendidikan-baik pada masa klasik maupun masa sekarang, bahkan dalam kajian fikih terdapat pembahasan khusus tentang perempuan, figh nis $\bar{a}^{\prime}$. Akan tetapi, perempuan hanyalah sebagai subyek pembahasan. Sehingga seringkali yang muncul dalam berbagai wacana pemikiran adalah perem-

*Doktor lulusan Program Pascasarjana IAIN Syarif Hidayatullah Jakarta dengan kosentrasi Pendidikan Islam ini adalah Guru Besar pada Fakultas Tarbiyah IAIN Imam Bonjol Padang. Ia juga adalah Ketua Program Studi Pendidikan Islam pada Program Pascasarjana IAIN Imam Bonjol Padang. 
puan sebagai subyek pemikiran, tidak terlibat dalam wacana pemikiran tersebut. Oleh karena itu, menjadi wajar apabila dibuka buku-buku atau kitab-kitab terkait, maka indeksnya akan dipenuhi oleh nama laki-laki, sedang nama-nama perempuan hanya disebut apabila kajian itu membicarakan tentang sejarah perempuan.

Menjadi menarik untuk didiskusikan, mengapa tokoh-tokoh perempuan dalam perjalanan sejarah Islam tertinggal beberapa langkah dibanding dengan tokoh laki-laki? Bahkan, dalam beberapa kasus atau kurun waktu tertentu, tokoh perempuan semakin jauh tertinggal, untuk tidak dikatakan tidak ada sama sekali. Sejarah ulama perempuan adalah sejarah yang gelap, demikian istilah yang digunakan Azyumardi Azra. ${ }^{1}$ Tidak banyak yang dapat diketahui dari subyek ini, sehingga informasi yang dapat digali sangat terbatas.

Meski demikian, bukan berarti sejarah pendidikan perempuan, khususnya yang terkait dengan tokoh-tokohnya, tidak ter-cover sama sekali dalam data sejarah. Terdapat beberapa sumber yang dapat memberikan data-data sejarah antara lain dari kamus-kamus biografi. Ruth Roded ${ }^{2}$, umpamanya, dalam penelitiannya menyusun 38 kitab koleksi biografis Islam yang memuat nama perempuan. Kitab-kitab biografi yang diteliti antara lain karya Ibn Sa'ad (230 H./845 M.). ${ }^{3}$ Dalam kitab Thabaqat, ia menyebutkan 629 perempuan dari 4250 entri yang disusunnya. Hal ini berarti hanya $15 \%$ dari keseluruhan entri yang ditulisnya. Ibn Sa'ad termasuk tokoh yang banyak memasukkan entri perempuan dalam koleksi biografisnya dibandingkan dengan beberapa penulis biografis lainnya. Al-Khatib al-Baghdadi (463 H./1070 M.), umpamanya, hanya menyebutkan 31 nama perempuan dari 7800 entri yang disusunnya. Hal ini berarti kurang dari $1 \%$ dari seluruh jumlah tokoh yang ditulis. Sementara Ibn 'Asakir (571 H./1176 M.) hanya menyebutkan 200 nama perempuan dalam 13.500 entri yang disusunnya. Kemudian Fariduddin al-Attar (628 H./1230 M.) ${ }^{4}$, dalam karya populernya Tadzkirah al-Auliya' hanya menyebutkan satu nama dari 72 para sufi yang ditulis biografinya, yaitu Rabi'ah al-Adawiyah (w. 185 H.). Ibn Khalikan (681 H./1282 M.) memasukkan 6 tokoh perempuan dalam 826 entri yang ditulisnya (kurang dari 1\%). Jami (898 H./1492 M.) memasukkan 35 nama perempuan dalam 564 entri yang disusunnya. Al-Sakhawi (902 H./1497 M.) menulis 1075 entri perempuan dari 11.691 keseluruhan entri yang disusunnya (9\%). Adapun Al-Ghazzi (1061 H./1651 M.) hanya menyusun 12 nama perempuan dari 1647 nama dalam koleksi biografisnya.

Permasalahan yang coba dijawab dalam pembahasan berikut adalah siapakah tokoh-tokoh perempuan yang tercatat dalam sejarah, khususnya 
yang terlibat dalam proses pendidikan? Apakah bidang-bidang yang digelutinya? Apakah peran yang telah dimainkannya? Dan mengapa sejarah pendidikan perempuan mengalami 'keterputusan sejarah' sehingga tertinggal jauh dari pendidikan laki-laki?

\section{TOKOH PEREMPUAN DALAM BERBAGAI BIDANG KEILMUAN}

Sudah umum diketahui besarnya peran yang dimainkan oleh para istri Nabi saw. serta para sahabat perempuan dalam berbagai kancah kehidupan, khususnya dalam mentransmisikan hadis Nabi saw., sehingga namanya terukir dalam sejarah peradaban Islam. Pada saat itu, belum ada klasifikasi ilmu - sebagaimana yang terjadi pada masa sesudahnya, apalagi dikhotomi ilmu-maka seorang tokoh boleh jadi concern, untuk tidak menyebut menguasai, berbagai bidang sekaligus. Dapat disebut sebagai contoh adalah Ummul Mukminin, Aisyah, istri Rasulullah, di samping menguasai bidang hadis, ia juga menguasai tafsir dan fikih.

Dalam dunia pendidikan pada periode pertama Islam, khususnya masa Nabi, terdapat persamaan dalam kesempatan menuntut ilmu, tidak membedakan antara laki-laki dan perempuan. Ini antara lain dapat dilihat dari beberapa asbāb al-nuzūl suatu ayat atau asbāb al-wurūd suatu hadis yang didahului dengan beberapa permasalahan yang diajukan kepada Rasulullah. Perempuan tidak segan untuk langsung bertanya dan mengajukan permasalahannya kepada Rasulullah, walaupun dalam penjelasannya Aisyah ikut perperan menjelaskan persoalan yang bersifat khusus perempuan, sehingga perempuan itu akan malu jika dijelaskan oleh Rasulullah. Dengan demikian perempuan terlibat aktif dalam proses belajar mengajar, yang pada saat itu belum ada pendidikan formal.

Dalam masa selanjutnya, tidak ditemukan data sejarah yang menyebutkan adanya kesempatan atau kondisi yang sangat mendukung terjadinya proses belajar sebagaimana yang terjadi pada periode pertama. Meskipun demikian, bukan berarti tidak ada tokoh perempuan yang muncul dan menguasai ilmu dalam berbagai bidang. Bidang-bidang yang mendapat perhatian dari para tokoh perempuan antara lain: fikih, tafsir, hadis, dan tasawuf, serta beberapa bidang lain, seperti syair, 'ilmu al-thibb (ilmu kedokteran), kaligrafi, dan sebagainya. Sebelum membahas permasalahan ini, terlebih dahulu dikemukakan beberapa tokoh perempuan yang concern terhadap beberapa bidang. Perlu digarisbawahi bahwa pembidangan ini adalah untuk menyederhanakan pembahasan, sebab tidak menutup kemungkinan seorang tokoh menguasai berbagai bidang sekaligus, sehingga disebut beberapa kali dan terlihat adanya over lapping. 


\section{Bidang Fikih}

Dalam bidang fikih, misalnya, antara lain tercatat tokoh sebagai berikut: 'Amra binti Abdurrahman (98 H./716 M.)5; tokoh yang hidup pada masa tabi'in dan mempunyai hubungan dekat dengan Aisyah. Dia digolongkan sebagai orang yang memberikan fatwa di Madinah setelah sahabat-sahabat Nabi. Dia juga diakui sebagai ahli terkemuka mengenai hadis-hadis Aisyah dan dimintai komentar tentang hadis-hadis tersebut. Pendapatnya menggugurkan pandangan-pandangan para ahli hadis lainnya, dan ahli pertama yang mengangkat tiga isu hukum yang berkenaan dengan larangan menggali kembali kuburan, menjual buah yang belum masak, dan pengaruh kerusakan tanaman pada penjualan produk pertanian. Terlihat bahwa pandangan-pandangannya bertentangan dengan para ulama tradisional, yang menghalangi perempuan mengemukakan bukti dalam masalah pembalasan dan hukuman.

Tokoh berikutnya adalah Hafsah binti Sirrin ${ }^{6}$, ahli hadis dari Basrah (diperkirakan w. 100 H./718 M.) yang terkenal takwa dan zahid. Hafsah membaca al-Qur'an pada usia 12 tahun, ia sangat ahli sehingga saudarasaudaranya bertanya pada bagian-bagian tertentu yang sulit dan tidak jelas. Satu catatan menarik adalah saat seorang laki-laki mendatanginya, ia menabiri wajahnya dengan jubah. Oleh sebab itu, ia dikritik oleh para lelaki tersebut yang mendasarkan kritikannya pada ayat al-Qur'an. Iapun menjawab kritikan itu dengan mendasarkan pada al-Qur'an pula. Masih dalam bidang ini, tokoh lainnya adalah Aisyah binti Thalhah, cucu Abu Bakar al-Shidiq, dan Ummu al-Banin 'Atikah. Tokoh yang disebut pertama, misalnya, banyak meriwayatkan hadis dari bibinya, antara lain tentang kebolehan suami mencium istrinya ketika puasa. ${ }^{7}$

Nama perempuan yang tercacat sebagai ahli hukum pada abad ke-4 Hijrah adalah Ummu Isa binti Ibrahim (328 H./939M.) dan Amah al-Wahid (377 H./987 M.). Tokoh yang disebut terakhir ini adalah putri dari Hakim Abu Abdullah al-Husain al-Muhamili, belajar pada ayahnya dan guruguru yang lain. Setelah menghafal al-Qur'an, dia mempelajari fikih mazhab Syafi'i dan peraturan-peraturan kompleks tentang pewarisan dan penghitungan bagian ahli waris. Dia mengeluarkan fatwa bersama dengan mufti laki-laki. Tokoh perempuan lain yang ahli dalam bidang ini adalah Fatimah dari Samarqand, yang hidup di Aleppo pada abad 6 H./12 M. Dia belajar hukum Hanafi dari ayahnya dan menghafalkan berbagai kompilasi hadis karya ayahnya. Fatwa-fatwanya pun dikeluarkan di bawah nama mereka berdua. Pada abad ke 7 H./13 M., tercatat dua tokoh perempuan ahli hukum, yaitu: 'Ain al-Syam binti Ahmad (610 H./1213 M.) dari Isfahan 
dan Ummu al-Baqa Khadijah binti al-Hasan (641 H./1243 M.) dari Damaskus. Ummu Baqa Khadijah adalah seorang zahid yang mengabdikan diri pada hukum. Pada abad ke 8 H./14 M., tokoh perempuan yang tercatat sebagai ahli hukum antara lain Ummu Zainab Fatimah binti Abbas (714 H./1314 M.) dari Baghdad. Ia adalah penyair sufi dan penceramah yang memahami betul hukum Islam. Dia memberikan ceramah di depan perempuan di Damaskus dan Kairo, serta mengabdikan diri mempelajari hukum. Tokoh berikutnya adalah Ummu al-`Izz Nudar binti Ahmad (702 H./1302 M.), putri seorang alim dan belajar pada syaikh di Kairo. Nudar mampu membaca dan menulis serta menggubah syair yang mengandung pelajaran moral, yang dilestarikan oleh ayahnya. ${ }^{8}$

Sementara al-Sakhawi menyebut beberapa nama ahli hukum abad 9 H./15 M., antara lain: Aisyah binti Ali (761-840 H./1359-1436 M.)-yang dikenal sebagai Ummu Abdillah, Ummu Fadhl, dan Sitt al-Ayisy-pengikut madzhab Hambali dari Kairo, yang memulai karirnya dengan dibawa ke hadapan kakeknya yang terkemuka dan ulama-ulama lainnya. Dia menerima ijazah dari sejumlah guru Suriah dan Mesir, membaca al-Qur'an, belajar menulis indah, belajar sejarah, hadis, dan syair serta kitab-kitab hukum. Muridnya antara lain Ibn Hajar al-Asqalani. Tokoh lain dalam abad ini adalah Ummu Hani Maryam (778-871 H./1376-1466 M.) yang diajak kakeknya untuk mendengar sedikitnya dari 9 guru di Makkah dan Kairo, dan menerima ijazah sedikitnya dari 12 guru lain. Dia hafal alQur'an sejak kecil dan mempelajari sebagian besar dari 6 kitab hadis, terutama Bukhari, dan mempelajari kitab tentang fikih. ${ }^{9}$

Sedangkkan tokoh perempuan ahli hukum yang tercatat dalam abad 10 H./16 M., antara lain: Aisyah al-Ba'uniyah binti Yusuf (922 H./1516 M.), seorang syaikhah ahli sufi yang menulis beberapa kitab tasawuf yang kemudian dibawa ke Kairo, di mana ia dapat wewenang untuk mengajar dan memberikan fatwa; Khadijah binti Muhammad al-Bailuni (930 H./1523 M.) adalah seorang ahli fikih yang berasal dari Aleppine. Dia memilih madzhab Hanafi-yang barangkali dipengaruhi oleh gurunya, sebab ayah dan saudara-saudaranya bermadzhab Syafi'i-dan menghafal satu jilid buku tentang hukum Hanafi untuk melestarikan madzhab ini. Pada abad $12 \mathrm{H} . / 18 \mathrm{M}$., tokoh yang tercatat sebagai ahli dalam bidang hukum adalah Zubaidah binti As'ad (1194 H./1780 M.) yang mempunyai hubungan keluarga dengan kekaisaran Utsmaniyah. Menurut al-Muradi, Zubaidah mempelajari al-Qur'an, fikih, bahasa, dan sastra. Syair-syair yang diciptakan dalam bahasa Turki dan Persia sangat terkenal di kalangan penguasa dan masyarakat, sehingga karya sastranya dimuat dalam sebuah koleksi syair-syair ayah dan saudaranya. ${ }^{10}$ 


\section{Bidang Syair}

Tidak diragukan bahwa pada masa awal dinasti-dinasti dalam Islam, dunia sastra-khususnya syair-syair dan nyanyian-sangat diperhatikan. Sehingga tidak mengherankan bila kemudian muncul beberapa penyair, termasuk di dalamnya penyair perempuan. Abu Farraj al-Ishfahani (356 H./967 M.), misalnya, menyebut hampir 200 penyair wanita dalam kitabnya Akhbār al-Nisā' fi Kitäb al-Aghanni. ${ }^{11}$ Sebagian besar dari mereka adalah para sahabat perempuan dan mereka yang hidup pada masa tabi'in. Di antara nama-nama yang disebut adalah: Salamah al-Qash yang hidup semasa dengan Yazid bin Abdul Malik (101-105H./720-724M.), Khansa atau nama lengkapnya Tumadhir binti Amru bin Syarid al-Sulamiyah alMudhariyah, yang menciptakan puisi sebagai ungkapan duka-atas gugurnya empat putranya dalam perang Qadisyah serta dua saudaranya dan syair-syair kemanusian, ${ }^{12}$ Khaizuran, ${ }^{13}$ Jamilah al-Sulamiyah ${ }^{14}$ ahli musik dan pencipta beberapa lagu/syair. Para penyair tersebut berasal dari berbagai lapisan masyarakat, sehingga tidak sedikit dari mereka adalah para budak/hamba, seperti Jinan, jariyah Ali Abd al-Wahab bin Abd alMajid dan Wahbah, jariyah Muhammad bin Imran. ${ }^{15}$ Tokoh lainnya yang juga banyak menciptakan puisi adalah Rabi'ah al-Adawiyah. Wanita sufi ini, misalnya, banyak mengungkapkan suasana perasaan cintanya kepada Ilahi melalui syair-syair. ${ }^{16}$

Menjadi wajar mengapa syair berkembang dengan baik dan menempati posisi yang penting dalam kebudayaan Arab pada waktu itu, sebab syair dan musik merupakan dua bagian yang integral dalam kultur Arab sebelum datangnya Islam. Penyair dan penyanyi saat itu sangat dihormati. Karya-karya mereka dikoleksi dan dipelajari sejajar dengan ilmu-ilmu keagamaan.

\section{Bidang Hadis}

Bidang hadis adalah bidang yang paling banyak memunculkan tokoh-tokoh perempuan. Hampir semua istri Rasulullah mempunyai keahlian dalam meriwayatkkan hadis. Dalam bidang ini terdapat tiga peran yang telah dimainkan oleh para sahabat perempuan (shahabiyat). Pertama, sebagai murid langsung Rasulullah. Jumlah hadis yang diriwayatkan oleh sahabat perempuan tersebut menunjukkan keterlibatan mereka secara aktif dalam meriwayatkan hadis Nabi saw. Tercatat beberapa nama perempuan yang menjadi perawi hadis, antara lain: Aisyah binti Abu Bakar (meriwayatkan 2210 hadis), Ummu Salamah binti Zadur Rakb atau Hindun binti Abu Umayyah (meriwayatkan 387 hadis), Maimuah binti alHaris (meriwayatkan 76 hadis), Ummu Habibah binti Abu Sofyan (meri- 
wayatkkan 65 hadis), Shafiyah binti Huyai (meriwayatkkan 10 hadis). ${ }^{17}$ Kedua, sebagai komunitas yang peduli pada persoalan perempuan dan persoalan umat pada umumnya. Ini misalnya dapat dilihat dengan ditunjuknya Asma' binti Yazid ${ }^{18}$ sebagai 'juru bicara' di kalangan perempuan saat itu, khususnya dalam mengajukan permasalahan kepada Nabi saw. Di samping itu, komunikasi yang intensif dengan Ummahat al-Mukminin, komunitas tersebut sangat berfungsi sebagai 'penyambung lidah' Nabi kepada para sahabat. Ini pula yang ikut berperan dalam sosialisasi hadishadis Nabi. Ketiga, berperan sebagai generasi perintis periwayatan Hadis. Para sahabat perempuan tersebut ikut berperan dalam mentransmisikan hadis Nabi, di samping itu juga berjasa dalam pembukuan Hadis. M. M. Azami mencatat 6 nama tokoh perempuan yang meninggalkan tulisan berisi hadis Nabi, yaitu: Asma' Binti Umais (menyimpan shahifah berisi hadis Nabi), Subai'ah al-Aslamiyah (meriwayatkan dan menulis hadis untuk para tabi'in), Aisyah (banyak mendiktekan hadisnya pada Ziyad bin Abu Sufyan, Urwah bin al-Zubair, dan Mu'awiyah bin Abu Sufyan), Fatimah al-Zahra (menyimpan shahifah yang berisi wasiat-wasiatnya sendiri, yang dalam wasiat tersebut terdapat hadis-hadis Nabi), Fatimah binti Qais (mengimlakkan hadis-hadisnya pada Abu Salamah), dan Maimunah binti al-Harits al-Hilaliyah (meriwayatkan hadis-hadisnya kepada bekas hambanya, Atha' bin Yasar dan Sulaiman bin Yasar. ${ }^{19}$

Dalam bidang hadis, bila ditelusuri dari periwayatan hadis atau dari ilmu Rijāl al-Hadìts - meskipun perawinya perempuan namanya tetap Rijāl al-Hadits - maka dapat ditemukan tokoh-tokoh perempuan yang mengajarkan hadis, antara lain: Nafisah binti al-Hasan (208 H./ 824 M.) yang mengajarkan hadis kepada Imam Syafi'i, Ummu Umar al-Tsaqafuyah konon meriwayatkan hadis kepada Ibn Batutah. Demikian juga dengan al-Khatib al-Baghdadi belajar kepada empat perempuan, di antaranya dikutip dalam biografinya.

Pada masa selanjutnya, tercatat pula tokoh bernama Karimah binti Ahmad al-Marwaziyah, ahli terkemuka dalam bidang nash Bukhari; Syuhdah binti Abu Nash Ahmad al-Bari (574 H./1178 M.), yang mempunyai julukan 'Fahrun al-Nisa', mengajar 'al-Bukhari' dan karya-karya lain yang diterimanya dari ahli yang berkompeten kepada banyak murid. Dialah yang menjadi transmisi, penghubung antara ahli-ahli hadis generasi muda kepada generasi sebelumnya. Di samping itu, tokoh ini juga mengajarkan ilmu sastra, balaghah, dan syair. ${ }^{20}$ Zainab al-Sya'ari (615H./1218 M.) bertemu dan belajar kepada sejumlah ulama ternama dan mendapatkan ijazah untuk menyampaikan ilmu-ilmu yang dipelajarinya. Ibn Khalikan, ahli sejarah, termasuk yang menerima ijazah darinya. ${ }^{21}$ 
Untuk mempelajari hadis, misalnya, para tokoh perempuan tersebut haruslah mampu dalam segi ekonomi, untuk perjalanan atau rihlahnya dalam rangka mencari ilmu. Dengan demikian para ulama perempuan tersebut tidak hanya memiliki prestasi sosial, tetapi juga memiliki sumbersumber ekonomi, agar dapat mengabdikan ilmunya. Sebenarnya ajaran Islam mendukung hal ini dan sangat menguntungkan perempuan, sebab seorang ayah dituntut untuk membiayai putrinya sampai menikah, dan suami harus menyediakan penghidupan yang layak bagi istrinya.

\section{Bidang Tasawuf}

Berbeda dengan bidang lainnya, dalam wilayah tasawuf/mistisisme, perempuan benar-benar mempunyai hak yang sama dengan laki-laki, sehingga menjadi wajar jika kemudian banyak tercatat dalam sejarah nama sufi perempuan. Namun, acapkali dalam menerangkan masalah ini sering tidak lengkap. Seperti adanya beberapa nama yang sama, sehingga apabila tidak disebutkan secara lengkap namanya, atau kota kelahiran, tahun kelahiran atau wafatnya, dimungkinkan terjadi salah informasi. Bahkan ada yang tidak disebutkan namanya, hanya julukan atau diberi judul 'Perempuan yang Saleh'. Termasuk dalam hal ini Javad Nurbakhsh ${ }^{22}$, dari 124 tokoh yang diangkat dalam karyanya, Sufi Women, hanya Rabi'ah alAdawiyah secara agak lengkap dikupas, sementara yang lainnya hanya sedikit penjelasannya, itupun tanpa disertai dengan tahun kelahiran atau wafatnya, maupun tempat lahir dan wafat sufi tersebut, bahkan ada yang disebutkkan dengan identitas sebagai 'Gadis di Tepi Sungai', 'Perempuan di Ka'bah' dan beberapa kisah perempuan sufi yang tidak bernama lainnya. Ketidaklengkapan data tersebut menjadi wajar apabila kembali pada ajaran sufi itu sendiri yang seringkali cenderung melakukan suatu uzlah, bersikap rendah hati, bahkan menghindar dari kekuasaan. Padahal sejarah Islam yang ada sementara ini lebih mengedepankan sejarah politiknya daripada sosial intelektualnya. Walaupun begitu, tidak berarti para sufi perempuan tersebut tidak ter-cover dalam data sejarah, khususnya dalam biografi muslim. Sebagai suatu tambahan, kisah-kisah dalam dunia sufi sering kali tidak disebut sejarah (history), tetapi disebut dengan hagoigrafi, karena dalam ceritanya tidak jarang berbaur dengan kisahkisah yang bercorak mitos.

Abdurrahman bin Ali bin al-Jauzi (597 H./1200 M.) dalam biografinya tentang kaum sufi menyebutkan 240 perempuan, hampir seperempat dari seluruh jumlah entrinya. Para sufi yang tercatat dalam sejarah antara lain: Nafisah, lahir di Makkah tahun 145 H., adalah buyut dari Hasan bin Ali bin Abi Thalib. Ia besar di Madinah, tempat ia menghabiskan waktunya 
dengan bekerja keras dan beribadah kepada Allah swt. Ia wafat di Mesir 208 H. Ia sangat dikenal karena penguasaannya terhadap kitab al-Qur'an beserta tafsirnya dan sering mensyairkannya dengan syair keagamaan, sehingga mujtahid besar, Imam Syafi'i sering mengunjunginya dan mengadakan diskusi. ${ }^{23}$ Tokoh sufi berikutnya Isyi Nili, tinggal di Nisaburi.

Banyak kisah yang menyebutkan kecerdasan dari para sufi perempuan. Rabi'ah, misalnya, dijadikan tempat bertanya dan berdiskusi oleh para ulama saat itu. Sejak belia, Rabi'ah telah hafal al-Qur'an, sementara ilmu-ilmu lainnya banyak didapat dari berbagai tempat, terutama ketika ia menjadi penyanyi, sehingga Rabi'ah dapat menguasai beberapa bidang ilmu, khususnya mahabbah, atau pengetahuan yang berkaitan dengan kesucian jiwa, tasawuf. 24

Dzunnun al-Misri termasuk sufi yang meminta nasehat pada Fatimah di Nisapuri. Fatimah (223 H.) adalah terhitung sebagai ahli makrifat besar di kalangan perempuan sufi pada jamannya. Ia tinggal di Makkah, dan sering melakukan perjalanan ke Yerussalem, kemudian kembali lagi ke Makkah. Di samping Dzunnun al-Misri, Abu Yazid al-Bustami termasuk sufi yang memuji Fatimah. Di antara ucapannya adalah bahwa orang yang beramal agar bisa menyaksikan $\mathrm{Al}-\mathrm{Haq}$ adalah seorang 'arif, dan orang yang beramal agar Al-Haq menyaksikan dirinya adalah seorang 'abid. ${ }^{25}$ Tokoh sufi lainnya yang belajar pada perempuan sufi adalah Sufyan alTsauri, yang hidup hampir semasa dengan Rabiah al-Adawiyah.

Pada masa selanjutnya, sufi-sufi perempuan yang tercatat pada abad 8 H./14 M. adalah Aisyah dari Andalus (705-750 H./1305-1349 M.), Badi'ah binti Sirajuddin (890 H./1485 M.), seorang perempuan alim yang menyampaikan pengetahuan menulis syair.

Dari paparan data di atas terlihat bahwa nama-nama tokoh perempuan pada generasi pertama dan kedua (abad 1 dan 2 H.) muncul dalam jumlah yang relatif banyak dibandingkan dengan tahun-tahun berikutnya, kualitas dan kuantitas informasi tentang pendidikan perempuan menurun, sampai abad $8 \mathrm{H}$. Bila dikaji lebih jauh, kemunduran perempuan, khususnya dalam pendidikan, tidak terlepas dari penafsiran para ahli fikih pada masa Abbasiyah (abad ke 3 H./9 M.) yang merendahkan perempuan dalam Islam. Memang perlu dicermati dari koleksi-koleksi hadis dan tafsir al-Qur'an, apakah hadis Nabi mendukung pernyataan atau versi yang merendahkan perempuan? Atau apakah para mufasir al-Qur'an memberikan penafsiran yang merugikan wanita? Meski dari segi kuantitas dan kualitas merosot tajam, zona yang tidak terliput ini dapat dijembatani dengan cara megikuti jejak-jejak perempuan sebagai ulama, perawi, dan para sufi perempuan. 
Memang, apabila dilihat dari sisi tokoh perempuan, sebagaimana tersebut di atas, dengan berbagai keahlian dan keunggulannya, jumlah mereka tergolong kecil dibandingkan beratus-ratus, bahkan beribu-ribu laki-laki yang menggeluti ilmu. Pada abad ke $8 \mathrm{H}$., jumlah perempuan alim yang terekam dalam biografi meningkat. Hal ini antara lain disebabkan oleh banyaknya ulama laki-laki yang mengkhususkan diri pada biografi. Sebagai contoh adalah Ibn Hajar al-Atsqalani mengungkapkan 191 perempuan selama satu abad, dan 168-nya belajar dan menerima ijazah untuk menyampaikan ilmu mereka serta mengajar. Sebagian besar dari mereka mempelajari Bukhari-Muslim, 12 di antaranya bergelar musnidah. ${ }^{26}$ Sementara, Al-Sakhawi menjelaskan bahwa para perempuan yang disebutkan dalam biografinya bisa membaca dan menulis. Pada saat itu, perempuan yang melek huruf sangat terbatas, hanya terdapat pada segelintir nama, bahkan terdapat pula ulama dan guru-guru bersandar pada periwayatan lisan. Sementara al-Ghazzi menyebut 12 perempuan, 9 di antaranya adalah terpelajar. Salah satunya adalah Amah al-Khaliq (902 H./1496 M.) meriwayatkan 'Bukhari' dari penduduk Hijaz yang dapat dipercaya.

Pada masa selanjutnya, dalam biografi tidak banyak disebutkan para tokoh perempuan, paling hanya 1 atau 2 perempuan. Salah satunya adalah Maryam binti Muhammad al-'Aqqad (1220 H./1805 M.) yang menerima ijazah untuk menyampaikan koleksi hadis dari ayahnya dan ahli-ahli hadis termasyhur lain pada jamannya. Demikian juga, dalam bidang tasawuf, setelah abad ke 10 H./16 M., wanita-wanita sufi lenyap dari koleksi biografi, kecuali Ruqayyah (1317 H./1899 M.), putri syaikh tarekat Sya'diyah di Damaskus. Di samping itu, tercatat satu tokoh perempuan dari wilayah Afrika, Sokoto-sekarang masuk dalam wilayah Republik Nigeriabernama Nana Asma'u (1793-1865 M.). Dia adalah seorang guru, penyair dan pemimpin perempuan. ${ }^{27}$ Tidak tercatatnya para tokoh perempuan seiring dengan kemunduran peradaban Islam, yang menjadi daerah jajahan bangsa Eropa.

\section{PERAN PEREMPUAN DI BALIK LAYAR}

Seringkali perempuan berperan di balik layar dan tidak diragukan lagi bahwa peran tersebut sangat berpengaruh dalam perjalanan sejarah Islam. Akan tetapi, keterlibatan di balik layar ini, boleh jadi kemudian membuat perempuan tidak banyak terungkap dalam lembaran sejarah. Dalam mengambil keputusan, misalnya, tidak jarang perempuan sangat mempengaruhi keputusan yang ditetapkan, tetapi tidak dapat diketahui teori apa yang diterapkan dalam mempengaruhi keputusan tersebut, atau 
teori apakah yang ia ciptakan? Sementara dalam dunia pendidikan, tercatat beberapa perempuan yang mewaqafkan harta yang dimilikinya. Dengan begitu, perempuan selalu mendukung proses belajar mengajar.

Di antara perempuan yang sangat berpengaruh dalam pengambilan keputusan, bidang politik pemerintahan khususnya, adalah Ummu Yazid I (60-64 H./680-683 M.) yang sangat berpengaruh pada suami dan putranya; Ummu Salamah istri Abu al-Abbas (132 H./749 M.), pendiri dinasti Abbasiyyah; Khairuzan istri al-Mahdi (158-169 H./775-785 M.), yang mengendalikan Musa al-Hadi (169-170 H.); Zubaidah (173 H./789 M.) istri Harun al-Rasyid; Al-Tutunjan (452 H./1060 M.) selir sultan Seljuk; Shafiyah Khatun (581-640 H./1167-1242 M.), putri penguasa Ayyubiyah di Aleppo.

Wacana sejarah kaum perempuan yang mendukung kegiatan pendidikan Islam, pada umumnya dapat dilihat dari kedermawanan mereka dalam membangun dan memberikan wakaf pada madrasah-madrasah, mesjid-mesjid, pondok sufi (zawiyah/ribath/khanaqah), mausoleum, serta sarana umum lainnya, seperti saluran air. Dapat disebut sebagai contoh adalah Zumurrudz Khatun (557 H./1161 M.), seorang alim dari elit penguasa, membangun dan mewakafkan salah satu mesjid-madrasah yang besar dengan madzhab Hanafi di Damaskus. Selain itu, disebutkkan pula bahwa dia mewakafkan yang lainnya. Ismah al-Din al-Khatun (581 H./ 1185 M.) memberikan banyak batas kepada sebuah madrasah untuk pengikut madzhab Hanafi. Rabi'ah Khatun, keluarga penguasa Ayyubiyah, membangun dan mewakafkan sebuah madrasah di Damaskus untuk madzhab Hambali atas saran sahabatnya yang alim. Pada abad 10 Hijrah, seorang perempuan Damaskus - tanpa disebutkan identitasnya-mewakafkan rumah yang diwarisi dari ayahnya pada mesjid agung kaum Hambali. ${ }^{28}$

Sementara di Kairo, misalnya, sebelum dan pada masa Mamluk sekurang-kurangnya terdapat lima madrasah yang didirikan perempuan. Madrasah tersebut bisa berbentuk pondokan/zawiyah, yaitu: pertama, Madrasah 'Asyuriyyah, istri seorang Amir, di lingkungan Zuwayla, Kairo; Kedua, Madrasah al-Qutbiyyah yang didirikan oleh Ismet al-Din, putri Sultan Ayubiyyah; al-Malik al-Adil, dan saudara perempuan al-Malik alAfdhal Qutb al-Din Ahmad. Oleh karena itu, madrasah yang didirikan pada akhir abad 13 M. ini juga dikenal sebagai Madrasah 'Ismad al-Din. Ketiga, Madrasah Hijaziyyah didirikan dan diwakafkan oleh putri Sultan al-Nasir Muhammad, yang menikah dengan Amir Mamluk bernama Bahtimur al-Hijazi. Nama yang terakhir disebut kemudian diabadikan sebagai nama madrasah tersebut. Selain madrasah, sang putri ini juga membangun kubah, yang pada gilirannya menjadi tempat peristirahatan 
terakhirnya ketika wafat. Madrasah ini terkenal dengan spesialisasi dalam bidang fikih Syafi'i dan Maliki. Keempat, madrasah yang didirikan Barakat, ibu Sultan Asyraf Saban (1369-1370 M.), yang terkenal khususnya dalam bidang fikih madzhab Syafi'i dan Hanafi. Dan kelima, Madrasah Ummu Khawand yang didirikan Fatimah binti Qanibay al-Umari al-Nasiri, istri tentara Mamluk bernama Thaghri Birdi al-Muadzdzi. ${ }^{29}$

Perempuan lain yang terkenal dengan wakafnya adalah Zubaidah, yang membuat saluran air. Ini dilakukan setelah melihat sulitnya air di Makkah waktu menjalankan ibadah haji, sehingga orang-orang yang menunaikan rukun Islam kelima ini merasa kesukaran mendapatkan air. ${ }^{30}$ Tokoh lainnya adalah Syaghab, ibu khalifah al-Muqtadir (321 H./933 M.), dan Arghun al-Hafiziyah (648 H./1250 M.) yang mewakafkan rumahnya serta membeli beberapa kebun buah-buahan untuk diwakafkan pada sebuah madrasah dan mausoleum yang dibangunnya. Satu catatan menarik adalah bahwa hanya $10 \%$ dari wakaf yang diberikan perempuan tersebut dikelola perempuan, dan semakin besar wakaf yang didermakan, semakin kecil proporsi pengelolaannya pada perempuan. Perempuan sendiri-yang mendirikan wakaf tersebut-lebih suka harta wakafnya dikelola oleh kaum Adam. Peran-peran seperti inilah yang banyak dimainkan perempuan di balik layar.

\section{MENGUPAS PERMASALAHAN PENDIDIKAN PEREMPUAN: SEBUAH ANALISA AWAL}

Bila dibandingkan dengan tokoh laki-laki dengan tokoh perempuan yang tercatat dalam data sejarah, maka jumlahnya terlihat tidak seimbang. Ketidakseimbangan tersebut dapat dilihat dari berbagai sisi. Kemerosotan jumlah ahli hadis perempuan, misalnya, menunjukkan adanya pandangan yang lebih atau mengutamakan laki-laki, meskipun ada perempuan yang keandalannya dapat dipercaya. Pengistimewaan ini boleh jadi merupakan hasil dari pengetahuan sadar atau dari pola-pola sosial yang membuat hubungan antara ulama laki-laki dan perempuan jadi problematis. Hal ini sejalan dengan apa yang dikemukakan oleh Laila Ahmad bahwa pelestarian tradisi Sassan Persia dalam masyarakat Abbasiyah menciptakan suasana yang membatasi gerak perempuan. Di samping itu, tidak terekamnya sejarah perempuan dimungkinkan semakin diperketat standarnya, sebagaimana tercatat sejumlah ulama dalam berbagai bidang yang namanya hingga kini termasyhur. Sebagaimana lazim diketahui bahwa pada masa Rasulullah saw. terdapat beberapa perawi perempuan yang tercatat dalam sejarah periwayatan hadis Nabi. Demikian pula perempuan yang mampu membaca dan menulis serta mengajarkannya pada yang lain, 
namanya tercatat dalam sejarah Islam. Namun, pada masa selanjutnyakhususnya pada masa kejayaan Islam - dengan perkembangan yang begitu pesat dalam berbagai bidang, maka tokoh-tokoh yang berjasa dan populer-seperti ahli filsafat, ahli tasawuf, ahli hukum, ahli tafsir, ahli hadis, dan sebagainya yang namanya hingga kini masih diperhitungkan dan dijadikan rujukan-telah terekam dalam sejarah Islam. Tingginya standar yang digunakan sebagai kriteria inilah yang ikut berperan dalam menurunkan jumlah tokoh perempuan dalam data-data sejarah.

Pada sisi lain, tampakya, meskipun perempuan dalam teori mampu menjadi mufti, tetapi tidak banyak perempuan yang ahli dalam bidang hukum untuk mengisi posisi tersebut. Relatif terkemukanya perempuan dalam bidang hadis, dibandingkan dengan yang belajar ilmu hukum, mungkin disebabkan oleh harapan-harapan tentang masa depan. Tentu tidak banyak harapan perempuan atau orangtua mereka agar anaknya menjadi mufti, apalagi qadhi. Pendapat bahwa analisis perempuan kurang, sedang kemampuan tersebut diperlukan dalam bidang hukum, sementara pengetahuan tentang hadis hanya diperlukan hafalan, kiranya mencerminkan pandangan sebagian muslim saat itu.

Ikatan kekeluargaan ikut pula berpengaruh pada pendidikan perempuan, khususnya dalam periwayatan seorang perempuan. Hubungan keluarga inilah yang membuat perempuan mendapatkan kesempatan untuk belajar. Menurut al-Sakhawi, sebagaimana diteliti dan dijelaskan kembali oleh Ruth Roded, 31 bahwa $20 \%$ perempuan belajar dari guru lakilaki yang merupakan anggota keluarga, $15 \%$ belajar dari guru perempuan yang juga ada ikatan keluarga. Pada bagian lain disebutkan bahwa $35 \%$ perempuan belajar hanya dari guru laki-laki yang adalah keluarganya, dan terdapat $88 \%$ dari perempuan tersebut diajari khusus oleh keluarganya sendiri.

Keabsahan perempuan sebagai penyampai informasi pada masa Nabi tidak menjadi masalah, seperti yang dilakukan oleh Aisyah, Hafsah, dan lain-lain. Pada masa selanjutnya, persoalan muncul tatkala dihadapkan pada masalah: apakah perempuan dapat menjadi qadhi (hakim) dalam yurisprudensi hukum (fikih) Islam? Ditambah dengan penafsiran para ulama terhadap beberapa ayat al-Qur'an yang mengatakan bahwa laki-laki adalah pemimpin wanita (Q.S. al-Nisa': 38), semakin membuat posisi perempuan termarginalkan. Bahasa yang digunakan dalam ayat-ayat alQur'an secara tekstual terlihat lebih memihak laki-laki dibanding dengan perempuan - sehingga menimbulkan penafsiran yang tidak menguntungkan perempuan-ikut pula dijadikan sebagai faktor marginalisasi perempuan, khususnya dalam wilayah publik. 
Menurut Fatimah Mernisi, 32 marginalisasi perempuan dalam sejarah Islam tercipta karena dua hal. Pertama, semangat tribalisme Arab yang tumbuh kembali setelah Rasulullah wafat. Kedua, pemahaman ajaran agama yang berkaitan dengan perempuan lepas dari kaitan historisnya. Dengan bahasa yang agak keras, Mernissi menganggap bahwa keterbelakangan perempuan Islam merupakan penyelewengan sejarah yang dilakukan para penguasa Islam sepeninggal Rasulullah.

Dalam masalah yang sama, hijab dapat pula dijadikan sebagai faktor ketertinggalan perempuan dalam pendidikan. Menurut Fatimah Mernisi33, hijab dilembagakan pada masa dinasti Umayyah, yang kemungkinan dibawa dari budaya Sasanid. Penyekatan ini juga dikenal dengan istilah satr, yang kemudian membuat perempuan tidak bebas bergerak untuk mendapatkan ilmu dan membuat kesempatan yang didapat perempuan sangat terbatas. Asghar Ali Engineer berpendapat senada, bahwa usaha pengerudungan (purdah) mulai berkembang pada masa Umayyah. Pada masa Nabi, hijab atau jilbab tidak dipersoalkan. Akan tetapi, pada masa belakangan, ketika pengaruh asing masuk, terutama pengaruh Roma dan Persia muncul ke permukaan, perempuan semakin dibebani dengan pembatasan-pembatasan. Para penguasa memelihara harem dalam jumlah yang tidak sedikit, sehingga dibutuhkan penjagaan yang ketat dari luar. Segera setelah itu cara-cara penguasa tersebut diikuti para anggota keluarga penguasa atau kalangan elit penguasa, dan akhirnya diikuti oleh masyarakat pada umumnya. Lambat laun perempuan dilarang datang ke masjid untuk berjamaah. ${ }^{34}$ Semua ini tidak terlepas dari pemahaman para ahli fikih terhadap ajaran Islam yang berkembang pada saat itu.

Permasalahan ekonomi juga dapat dijadikan sebagai faktor yang membuat pendidikan perempuan hanya terbatas pada kalangan menengah ke atas. Untuk mendapatkan keahlian dalam bidang hadis, misalnya, diperlukan biaya yang mahal untuk melakukan perjalanan panjang ke berbagai daerah yang dianggap sebagai pusat ilmu pengetahuan. Berguru pada sejumlah syaikh pun juga membutuhkan finansial dalam jumlah yang tidak sedikit. Hal ini semakin terasa sulit karena adanya pemahaman fikih yang mengharuskan perempuan ditemani oleh muhrimnya apabila bepergian, yang tentu saja turut menambah biaya pendidikan itu sendiri. Selain itu, kondisi demikian membatasi gerak dan ruang belajar bagi perempuan. Seandainya terdapat ahli hadis yang berasal dari hamba sahaya, maka ia cenderung dekat dengan elit penguasa. Dengan demikian, pendidikan, khususnya untuk perempuan, terbatas pada kalangan elit tertentu. Apalagi ketika lembaga pendidikan 'diformalkan' dalam bentuk madrasah, tidak ada seorang pun guru perempuan. Akan tetapi, mereka tetap belajar dan 
mengajar secara informal. Menurut Huda Lutfi dan Jonathan Berkey, sebagaimana dikutip kembali oleh Ruth Roded 35 , ulama-ulama perempuan pada masa Mamluk tidak menjadi guru di Madrasah, mereka juga tidak menduduki jabatan resmi. Birokratisasi terhadap kemapanan keilmuan mencapai puncaknya di bawah Utsmaniyah. Pada saat yang sama, perempuan tidak lagi dianggap sebagai ulama dalam koleksi biografi. Perempuan sebagai penyampai ilmu dan sebagai ulama ditentukan oleh kontak pengetahuannya dengan laki-laki, keandalan daya ingat, dan kebutuhan akan informasi yang dimilikinya.

\section{PENUTUP}

Sejarah pendidikan perempuan pada masa awal-masa Rasulullah saw.-terdata secara jelas dalam sejarah Islam. Pada periode awal ini terdapat kesempatan yang sama dalam pendidikan antara perempuan dan laki-laki. Kaum perempuan terlibat aktif dalam kegiatan belajar mengajar, sehingga muncul beberapa tokoh perempuan yang ahli di berbagai bidang. Berikutnya, seiring dengan masa kejayaan Islam, kesempatan pendidikan perempuan semakin terbatas, ini membuat nama perempuan tertinggaluntuk tidak dikatakan tenggelam-dalam berbagai bidang dan kesempatan. Dalam hal ini terdapat beberapa faktor yang dapat dimajukan, tetapi yang paling penting adalah legalitas fikih atau syariah yang begitu dominan terhadap lembaga-lembaga pendidikan Islam, sementara pemahaman fikih terhadap perempuan pada saat itu-bahkan juga masih ada yang dipraktekkan hingga sekarang - membuat gerak perempuan menjadi berkurang dan terbatas, khususnya yang berkenaan dengan wilayah publik.

Meskipun demikian, bukan berarti tidak ada tokoh perempuan yang bergelut dalam pendidikan. Bahkan, dalam catatan sejarah, utamanya yang bersumber dari biografi, menyebutkan nama-nama perempuan yang 'alim dalam berbagai bidang, khususnya dalam bidang agama, seperti Asma' dalam bidang hukum, Rabi'ah al-Adawiyah dalam bidang tasawuf, Nafisah binti Hasan dalam bidang hadis, Hafsah dalam bidang tafsir, Khansa dalam bidang syair, dan seterusnya.

\section{CATATAN AKHIR:}

1. Azyumardi Azra, "Membongkar Peranan Perempuan dalam Bidang Keilmuan", dalam Syafiq Hasyim (ed.), Kepemimpinan Perempuan dalam Islam, kumpulan makalah, Jakarta: JPPR, 1999, h. 69.

2. Ruth Roded, Kembang Peradaban, judul asli Women in Islamic Biographical Collection from Ibn Sa'd to Who's Who, terjemahan Ilyas Hasan, cetakan pertama, Bandung: Mizan, 1995, h. 19. 
3. Khusus mengenai biografi tokoh perempuan, lihat: Ibn Sa'ad, al-Thabaqat alKubra, jilid VIII, Beirut: Dar al-Fikr, tt.

4. Fariduddin al-Attar, Tadzkirah al-Auliya, terjemahan Anas Mahyuddin, Bandung: Pustaka, 1983.

5. Mengenai tahun wafatnya terjadi perbedaan pendapat: 98 H./716 M., $103 \mathrm{H}$./ 721 M., 106 H./724 M. Tahun yang disebut pertama menurut Ibn Hibban, tahun yang disebut kedua menurut al-Qaisarani, sementara Ibn Hajar yang mengutip pendapat beberapa ahli menambah satu lagi, tahun yang disebut ketiga. Apabila dilihat dari riwayat-riwayat tentang Khalifah Umar ibn Abd alAziz (99-101 H./717-720 M.), maka Amra meninggal sebelum pemerintahan Umar ibn al-Aziz. Lihat Ruth Roded, Kembang Peradaban, h. 93.

6. Kisah tentang Hafsah, antara lain diuraikan oleh: Ahmad Muhammad Jamal, Jejak Sukses 30 Wanita Beriman, judul asli: Namadzijul Mar'atul Muslimah, terjemahan Zaid Husain al-Hamid, cetakan pertama, Surabaya: Pustaka Progressif, 1991, h. 42-45.

7. Lihat misalnya: Ibn Sa'ad, al-Thabaqat al-Kubra, h. 467; Ruth Roded, Kembang Peradaban, h. 100-102.

8. Ruth Roded, Kembang Peradaban, h. 149-151

9. Ruth Roded, Kembang Peradaban, h. 151-152

10. Ruth Roded, Kembang Peradaban, h. 154

11. Abu al-Farraj al-Isfahani, Akhbār al-Nisā̄ fi Kitāb al-Aghanni, Abdul Ahyar Muhanna (ed.), cet. kedua, Beirut: Mu'assasah al-Kitab al-Tsaqafiyyah, 1993.

12. Abu al-Farraj al-Isfahani, Akhbār al-Nisā' fi Kitāb al-Aghanni, h. 110-112; bandingkan dengan: Ahmad Muhammad Jamal, Jejak Sukses 30 Wanita Beriman, h. 77-78.

13. Ahmad Muhammad Jamal, Jejak Sukses 30 Wanita Beriman, h. 112-114.

14. Ahmad Muhammad Jamal, Jejak Sukses 30 Wanita Beriman, h. 73-82.

15. Ahmad Muhammad Jamal, Jejak Sukses 30 Wanita Beriman., h. 397-398.

16. Atiyah Khamis, Rabi'ah al-Adawiyah, terjemahan Aliuddin Mahjuddin, Jakarta: Pustaka Firdaus, 1994, h. 22-24.

17. Lebih lanjut lihat: Syed Ahmad Semait, Seratus Tokoh Wanita Terbilang, cetakan IV, Singapura: Pustaka Nsional, 1993, h. 153, 170, 190, dan 197.

18. Kisah tentang Asma' lebih lanjut, lihat: Ahmad Muhammad Jamal, Jejak Sukses 30 Wanita Beriman, h. 47-51.

19. M. M. Azami, Hadis Nabi dan Sejarah Kodofikasinya, terjemahan Ali Mustafa Ya'qub, Jakarta: Pustaka Firdaus, 1994, h. 142, 154, 161, 197, 198, dan 199.

20. Ahmad Salaby, Sejarah Pendidikan Islam, terjemahan Muhtar Yahya dan M. Sanusi Latif, Jakarta: Bulan Bintang, 1973, h. 344.

21. Ruth Roded, Kembang Peradaban, h. 122-123.

22. Lebih lanjut lihat Javad Nurbakhsh, Sufi Women, cetakan kedua, London: Kaniqah Ni'matullahi Publication, 1990.

23. Margaret Smith, Rabi'a The Mystic \& Her Fellow Saint in Islam, London: Cambridge University Press, 1928, h. 39, 63-65.

24. Fariduddin al-Attar, Tadzkirah al-Auliya, h. 60-61.

25. Fariduddin al-Attar, Tadzkirah al-Auliya, h. 164-165.

26. Fariduddin al-Attar, Tadzkirah al-Auliya, h. 124-125. 
27. Jean Boyd, The Chaliph's Sister; Nana Asma'u (1793-1865) Teacher, Poet, and Islamic Leader, London: Frank Cass, 1995.

28. Banyaknya wakaf yang diberikan oleh perempuan inilah yang menarik Ruth Roded untuk melakukan penelitian tentang biografi perempuan dalam sejarah Islam. Dalam penelitiannya terhadap kamus biografi Suriah periode Utsmaniyah, dan ketika melakukan studi atau penelitian kuantitatif atas wakaf di Aleppo Utsmaniyah, tercatat $41 \%$ adalah dari kaum perempuan. Sedikit berbeda dengan wakaf kaum laki-laki, proporsi kaum perempuan sebagai pendiri wakaf relatif besar. Lihat Ruth Roded, Kembang Peradaban, h. 9.

29. Azyumardi Azra, "Membongkar Peranan Perempuan dalam Bidang Keilmuan", h. 80.

30. Sebagaimana diceritakan dalam perjalanan Ibnu Batutah. Lihat; Rass E. Nun, Petualangan Ibn Batutah; Seorang Musafir Muslim Abad ke 14, terjemahan Amir Sutaarga, Jakarta: Yayasan Oobor, 1995, h. 124.

31. Ruth Roded, Kembang Peradaban, h. 140.

32. Fatimah Mernisi, Women and Islam, Oxford: Basil Balckwell, 1991, khususnya bagian 2 dan 3.

33. Fatimah Mernisi, The Veil and The Male Elit: A Feminist Interpretation of Women Rights in Islam, Massachusetts: Addison, 1991, h. 120.

34. Asghar Ali Angeneer, Hak-hak Perempuan dalam Islam, judul asli 'The Rights of Women in Islam, terjemahan Farid Wajidi \& Cici Farkha Assegaf, cetakan pertama, Yogyakarta: Bentang Budaya, 1994, h. 131.

35. Ruth Roded, Kembang peradaban, h. 157.

\section{DAFTAR PUSTAKA:}

Angeneer, Asghar Ali, Hak-hak Perempuan dalam Islam, terjemahan Farid Wajidi \& Cici Farkha Assegaf, cetakan pertama, Yogyakarta: Bentang Budaya, 1994.

Al-Attar, Fariduddin, Tadzkirah al-Auliya, Nicholson (ed.), London: 1983.

Azami, M. M., Hadis Nabi dan Sejarah Kodifikasinya, terjemahan Ali Mustafa Ya'qub, Jakarta: Pustaka Firdaus, 1994.

Azra, Azyumardi, "Membongkar Peranan Perempuan dalam Bidang Keilmuan", dalam Syafiq Hasyim (ed.), Kepemimpinan Perempuan dalam Islam, kumpulan makalah, Jakarta: JPPR, 1999.

Boyd, Jean, The Chaliph's Sister; Nana Asma'u (1793-1865) Teasher, Poet, and Islamic Leader, London: Frank Cass, 1995.

Al-Isfahani, Abu al-Farraj, Akhbār al-Nisā' fi Kitāb al-Aghanni, Abdul Ahyar Muhanna (ed.), cetakan kedua, Beirut: Mu'assasah al-Kitab al-Tsaqafiyyah, 1993.

Jamal, Ahmad Muhammad, Jejak Sukses 30 Wanita Beriman, terjemahan Zaid Husain al-Hamid, cetakan pertama, Surabaya: Pustaka Progressif, 1991.

Khamis, Atiyah, Rabi'ah al-Adawiyah, terjemahan Aliuddin Mahjuddin, Jakarta: Pustaka Firdaus, 1994.

Mernisi, Fatimah, The Veil and The Male Elit: A Feminist Interprtation of Women Rights in Islam, Massachusetts: Addison, 1991.

Women and Islam, Oxford: Basil Balckwell, 1991. 
Nizar, Samsul (ed.), Sejarah Pendidikan Islam: Menelusuri Jejak Pendidikan Era Rasulullah sampai Indonesia, Jakarta: Kencana, 2007.

Nizar, Samsul, Memperbincangkan Dinamika Intelektual dan Pemikiran Hamka Tentang Pendidikan Islam: Menyongsong Seabad Buya Hamka, Jakarta: Kencana, 2008.

-------, Sejarah dan Pergolakan Pemikiran Pendidikan di Dunia Islam Era Awal dan Indonesia, Jakarta : Quantum Teaching, 2005.

Nun, Rass E., Petualangan Ibn Batutah; Seorang Musafir Muslim Abad ke 14, terjemahan Amir Sutarga, Jakarta: Yayasan Obor, 1995.

Nurbakhsh, Javad, Sufi Women, cetakan kedua, London: Kaniqah Ni'matullahi Publication, 1990.

Roded, Ruth, Kembang Peradaban, terjemahan Ilyas Hasan, cetakan pertama, Bandung: Mizan, 1995.

Sa'ad, Ibn, al-Thabaqat al-Kubra, jilid VIII, Beirut: Dar al-Fikr, 19--.

Salaby, Ahmad, Sejarah Pendidikan Islam, terjemahan Muhtar Yahya dan M. Sanusi Latif, Jakarta: Bulan Bintang, 1973.

Semait, Syed Ahmad, Seratus Tokoh Wanita Terbilang, cetakan keempat, Singapura: Pustaka Nasional, 1993.

Smith, Margaret, Rabi'a: The Mystic \& Her Fellow Saint in Islam, London: Cambridge University Press, 1928. 